\title{
1 Primary teachers as physical education curriculum change agents
}

\begin{abstract}
There has been some exploration of the conceptualisation of teachers as change agents within educational change literature. While this body of work does consider how teachers understand, harness and influence the process of curriculum change, within the policy rhetoric and educational change literature there is limited reference made to how the change agent role is translated into practice. To illustrate the complex nature of the change process this paper explores the experiences of generalist primary teachers at the 'chalk face' as they initiate physical education curriculum change within their school contexts. This paper reports on the findings of a study investigating how five Scottish primary teachers with a postgraduate qualification in primary physical education construed and took forward curriculum change. A qualitative and interpretivist approach to the research was taken to analyse how the knowledge and skills the teachers gained from the professional development they had undertaken contributed to their agency to initiate curriculum change within their school contexts. Drawing on the work of Fullan, the concept of change agentry is used to analyse the experiences of the individual teachers as they exercised their agency to enact curriculum change. The paper concludes by reflecting on the findings of the study to suggest factors that may support and constrain teachers acting as change agents.

\section{Keywords}

Change agent, Curriculum change, Primary physical education, Professional development, Teachers, Teacher agency
\end{abstract}

\section{Introduction}

The introduction of a new national curriculum in Scotland, Curriculum for

Excellence, has created a policy rhetoric assigning the responsibility for interpreting and developing the curriculum to individual schools and teachers.

Curriculum for Excellence allows for both professional autonomy and responsibility when planning and delivering the curriculum..... The framework provides flexibility....Such flexibility will result in a more varied pattern of curriculum structures to reflect local needs and circumstances. (The Scottish Government, 2008: 
1 Scotland is not alone in positioning teachers in this way; Priestley (2010) outlines how, over

2 the past decade, curriculum change has taken a similar stance across the Western world.

3 Furthermore, a tension has become evident between prescriptive, centrally driven curriculum

4 reform where teachers are positioned as recipients and deliverers of the curriculum, and

5 rhetoric encouraging teachers to interpret and assemble these guidelines into a curriculum

6 programme that takes account of local contexts (Kirk and Macdonald, 2001; Priestley, 2011;

7 Gray, Mulholland and MacLean, 2012).

The shift within policy rhetoric to position teachers as agents of change developing

9 the curriculum is problematic; particularly as the continuous barrage of centrally driven reform foisted on teachers over the past two decades has resulted in eroding the professional autonomy of the teaching profession, arguably creating a culture of compliance (Hargreaves and Goodson, 2006; Harris, 2011). There has been some exploration of the conceptualisation of teachers as change agents within education literature (see Fullan, 1993a; Kirk and Macdonald, 2001; Chen, 2005; Ertmer and Ottenbreit-Leftwich, 2010; Priestley, 2011). While this body of work does consider how teachers understand, harness and influence the process of curriculum change, there is limited reference made as to how the change agent role is translated into practice. Priestley, Edwards, Priestley and Miller. (2012) assert that: 'in order to understand the dynamic process through which change and continuity occur in educational settings' (p. 193) further research and theorising into the concept of teacher agency is required. Correspondingly, this paper reports on a study which investigated how individual teachers construed and took forward curriculum change within their school contexts. In this paper Fullan's (1993a) work on change agentry is used as a theoretical lens to understand how individual teachers took forward change. 
Viewing change as a process rather than an event, commonplace in modern society,

3 Fullan (1993b) proposes that: 'educators need the tools to engage in change productively' ( $\mathrm{p}$.

4 2). The main 'tools' Fullan (1993a) identifies as essential for supporting teachers to build

5 greater change capacity are 'moral purpose' and 'change agentry' (p. 8). Concomitantly,

6 Fullan (2003) proposes that in the twenty first century teachers also require 'informed

7 professional judgement' to negotiate the complex process of educational change (p. 5).

8 Informed professional judgement involves teachers developing knowledge and understanding

9 of curriculum and pedagogical innovations, and the education system so that they can apply their creative energies to take ownership of the change process.

Fullan suggests that central to teachers being able to harness the change process is moral purpose - wanting to make a difference. Moral purpose keeps the teacher closely aligned to the needs of children and has the potential to lead teachers to engage in change agentry as they seek to bring about improvements in teaching and learning (Fullan, 1993a\&b). As a change agent the individual teacher engages in a learning process that encompasses four core capacities: personal vision building, inquiry, mastery and collaboration (Fullan, 1993a\&b). Complementary to individual change agentry, Fullan (1993a) recognises that institutional change at the school and system levels is also required, asserting that successful change requires both top-down (at the government, local authority level) and bottom-up (at the teacher, school level) strategies.

In the Change Forces trilogy (Fullan, 1993, 1999 and 2003) advice is offered on how teachers can develop the capacity to assert their professional voice and adopt a more proactive response to managing the forces of change. However, this commentary lacks detailed examples of teachers' thoughts on, and experiences of initiating change. The lack of 
1 detailed examples of bottom-up change in this work raises questions about how teachers

2 develop and exercise their agency within schools to influence curriculum change. In an

3 attempt to address this gap, the study which this paper reports on used the interlinked

4 concepts of informed professional judgment, moral purpose and change agentry to analyse

5 the experiences of individual teachers as they initiated curriculum change in physical

6 education within their school contexts.

\section{$7 \quad$ Contextualising the study - primary physical education}

Primary physical education provided the context within which the teachers involved in the study instigated curriculum change. Nationally and internationally concerns have been expressed about the preparedness of primary teachers to teach physical education and concurrently, the quality of learning experiences for children (e.g. Her Majesty's Inspectorate of Education (HMIE), 2001; Hardman and Marshall, 2001). Throughout the literature it is evident that there are a number of interrelated factors inhibiting primary teachers from delivering quality physical education programmes. These factors are both teacher-related, for example, teachers' perceptions of and confidence to teach physical education, and institutional factors outside of teachers' control such as provision of physical education within initial teacher education and professional development, time within the curriculum and resources (DeCorby and Halas 2005; Morgan and Hansen, 2007 and 2008a). Taken together, these factors can be perceived as barriers to teachers engaging with physical education and can subsequently be seen to impact adversely on the quality of physical education delivered in primary schools.

In an attempt to address the status of physical education and the quality of learning experiences within schools, the past two decades have seen a growing literature emerging critiquing the dominance of performative sport and health agendas within physical education 
1 (Penney and Chandler, 2000; Tinning and Glasby, 2002; Penney and Jess, 2004; Wright,

2 2004; Evans, 2013), coupled with literature promoting the educational value of physical

3 education (Bailey et al., 2009; Thorburn, Jess and Atencio, 2011; Kirk, 2010; Griggs and

4 Ward, 2012). Within this literature the dominance of the multi-activity block approach to the

5 curriculum has been questioned, particularly regarding the messages about physical education

6 and physical activity this approach re-produces (Penney and Chandler, 2000; Kirk, 2004;

$7 \quad$ Bailey et al., 2009; Griggs and Ward, 2012; Penney, 2013).

8 Within a Scottish context, attempts to address the preparedness of teachers and the quality 9 of primary physical education learning experiences for children have been aided by three key 10 policy developments: HMIE report (2001), Physical Activity Strategy (Scottish Executive, 11 2003) and The Review Group on Physical Education (Scottish Executive, 2004). A number of significant recommendations emerged from these reports, such as the repositioning of physical education within the curriculum, moving it from the Expressive Arts into the core area of Health and Wellbeing and mandating that all children should receive two hours of physical education each week throughout their primary and secondary schooling.

Additionally, another key recommendation, particularly significant to this paper, was investment in physical education professional development aimed specifically at primary teachers. The Scottish Government attended to this recommendation by funding postgraduate qualifications in primary physical education developed by the Universities of Glasgow and Edinburgh. These postgraduate qualifications offered the first in-depth, accredited professional development on physical education specifically for primary teachers within Scotland. All of the participant teachers involved in the study reported on in this paper were graduates of the Postgraduate Certificate in 3-14 physical education (PgCert), a two year parttime course devised by the University of Edinburgh. 


\section{The Professional Development}

The PgCert differed from other professional development in a number of ways (see; Jess and Campbell, 2012; Carse, 2013; Thorburn, Carse, Jess and Atencio., 2011). Firstly, the content and structure of the PgCert enabled links to be made between theory and practice, which is recognised as playing a central role in the effectiveness of professional development (Fraser, Kennedy, Reid, Mckinney, 2007). The PgCert comprised of three modules delivered mainly through after school and weekend workshops and seminars:

1. 3-14 Physical Education: Setting the Context

2. The Early Years Physical Education Curriculum (ages 3-8)

3. The Upper Primary / Early Secondary Physical Education Curriculum (ages 9-14)

During and after each module teachers had time to apply what they had learned within their school contexts through tasks and the culminating assignments. Secondly, in contrast to most physical education professional development, which tends to focus on the practical nature of the subject, the first module of the PgCert focussed on theory, policy and physical education research to set the context for the subsequent practical modules.

Finally, rather than providing lesson plans for teachers to follow, synonymous with the ineffectiveness of professional development, teachers were encouraged to reflect on their own values, attitudes, beliefs and context to develop a physical education curriculum to meet the needs of the learners they were working with (Thorburn et al., 2011). To extend and challenge the multi-activity block curriculum model the teachers were largely used to working with, the PgCert supported teachers to critique this model and introduced them to, through practical experience and literature, alternative physical education curriculum and pedagogical approaches such as Sport Education (see Siedentop, 1994), Teaching Games for 
1 Understanding (see Bunker and Thorpe, 1982; Kirk and MacPhail, 2002) and Basic Moves

2 (see Jess, Dewar and Fraser, 2004).

\section{$3 \quad$ Research design}

The study reported on in this paper involved working with five primary teachers over an extended period of time - an academic year, during 2010 and 2011. A qualitative and interpretivist approach to the research was taken, with the main aim of analysing how teachers engaged with long term professional development in primary physical education and how they put into practice knowledge and skills they had developed. The study also sought to explore the concept of educational change, attempting to understand the process of change from the teachers' perspective, viewing events and the social world through their eyes (Bryman, 2008).

Following ethical approval from the University of Edinburgh, the study employed a deliberate approach to sampling (Silverman, 2010), purposively selecting PgCert primary teachers because they provided an opportunity to study the relationship between professional development and educational change. The main criterion for selection of these participant teachers was that they had responded positively to the course, this meant they were known by the course tutors to be applying knowledge and skills gained from the course within their school contexts. ${ }^{1}$ Teachers responding positively to the course were viewed as likely to 'produce the most valuable data' (Denscombe, 2007: 17) because they best represented the research topic (Morse et al., 2002) - the relationship between professional development and educational change. This deliberate approach to sampling fit with the research methods and

\footnotetext{
${ }^{1}$ Many of the teachers who had completed the course remained in contact with the course tutors to inform them of their work in physical education and ask for advice. Accordingly, I consulted the course leaders to identify teachers that may have been interested in being involved with my study.
} 
1 the practicalities of conducting a small scale research study (Denscombe, 2007; Newby, 2 2010).

All of the participant teachers involved in the study (pseudonyms: Max, Jackson,

4 Lara, Imogen and Geoff) completed the PgCert between 2008 and 2009, had been teaching

5 for more than ten years and taught in large schools with between 300 and 400 pupils. Imogen,

6 Max and Jackson were employed in city schools while Geoff and Lara taught in small town

7 schools. When the participant teachers started the PgCert they were all employed on a full-

8 time basis within their schools as generalist class teachers. However, as a result of their

9 engagement with the PgCert, at the time of the research all of the teachers had additional

10 responsibilities for teaching physical education. Max and Jackson taught physical education

11 full-time within their school contexts, while Imogen, Lara and Geoff divided their teaching

12 time between their own class and teaching physical education to other classes in their

13 schools.

14 Research methods

Reflecting the interpretive nature of the research, both semi-structured and unstructured interviews, along with observations were utilised to allow interaction between the researcher and participant teachers. The timetable for the research was flexible so that the gathering of data did not impinge on the teachers' heavy workloads and timetables. The three semi-structured interviews were conducted across the academic year. The first interview, at the beginning of the fieldwork (around July/August) attempted to establish the teachers' physical education backgrounds and their 'typical' pedagogical practices before commencing the PgCert. Whilst acknowledging the complexities of asking the teachers to recall practice they were no longer engaged in, this was deemed a valuable line of enquiry to initiate the 
1 research process as it enabled me, as the researcher, to establish the back story of the teachers

2 and build a rapport with them (Bogdan and Biklen, 1982). Following on from the first round

3 of interviews, the second interview (around September/October) concentrated on the

4 teachers' practice after completing the PgCert. The final interview, towards the end of the

5 fieldwork (around March/April), provided the opportunity to follow up on themes emerging

6 from the previous interviews, clarify physical education terminology used by the teachers and

7 explore the concept of change.

Complementary to the semi-structured interviews, three unstructured interviews were conducted with the teachers. The semi-structured and unstructured interviews lasted for around one hour, were digitally recorded and transcribed in full. The unstructured interviews were not guided by an interview schedule (Cohen, Manion and Morrison, 2007), and were called planning conversations because the main intention behind them was to encourage the teachers to talk openly about their physical education planning, teaching and evaluations. The planning conversations were conducted on three occasions within the academic year, in August, January and April which corresponded with the teachers' planning cycles. Although the planning conversations were not entirely spontaneous, as they were arranged in advance with the participant teachers, their tone was conversational (Punch, 2009). Rich data was generated by the planning conversations, providing an insight into the teachers' thought processes regarding how and what they taught. The planning conversations complemented the semi-structured interviews and related to the observations made of physical education lessons.

Drawing on a non-directive approach, the observations conducted were unstructured, but focussed and recorded in handwritten fieldnotes before being typed up (Freeman, 1982). The observations concentrated on the teacher and how they interacted with: the tasks they had 
1 set for lessons, the children, and the physical education learning environment. During the

2 observations the role of the researcher was not to judge and evaluate, but to clarify and understand. In scheduling observations I had to be flexible to reflect the teachers' timetables

4

and averaged around six observations for each teacher across the academic year. The data generated through the observations proved valuable in initiating discussion in both the semistructured interviews and planning conversations. $^{2}$

Reflecting on the research design I recognise the potential for bias because of the purposive sampling and the possibility that this would lead the participant teachers to respond in ways they thought was required of them. To address this, strategies were built into the study so that reliability and validity were continually evaluated (Morse et al., 2002). For example, I attempted to maintain an open and enquiring mind throughout the study by reflecting on my own subjectivity (Denscombe, 2007). Additionally, the research methods used within this study reflected: 'an attempt to secure an in-depth understanding of the phenomenon in question, through triangulation' (Denzin and Lincoln, 1998: 4). In this study triangulation involved looking at the phenomenon, the teachers' experiences of professional development and their subsequent engagement in curriculum change, from more than one perspective (Denscombe, 2007; Boeije, 2010). The interviews, observations and planning conversations provided three ways of interpreting the experiences of the teachers; comparing this data revealed that the teachers consistently reiterated their thoughts and experiences which contributed to the verification of their accounts and the validity of the research.

\footnotetext{
${ }^{2}$ While Geoff was part of the study he was unable to take part in planning conversations and only two observations could be made of his teaching. As this article is largely based on data from the planning conversations and observations no reference is made to Geoff within this paper.
} 


\section{Data analysis}

A large amount of textual data was gathered during the fieldwork phase of the study.

The interview transcriptions and fieldnotes were analysed drawing on a grounded approach to code the data and identify emergent themes (Charmaz, 2006; Punch, 2009; Boeije, 2010).

This iterative process of coding the data involved both induction and deduction. Ideas were formed inductively from the data by making connections between categories and themes: 'raising them to a higher level of abstraction' (Punch, 2009: 172). Correspondingly, in a deductive manner the emergent categories and themes were compared with relevant literature for verification (Punch, 2009). In relation to the interview data specifically used within this paper, inductive analysis was first applied to identify emergent themes. The data was then analysed in a deductive way coding it to correspond with Fullan's (1993a) description of informed professional judgement, moral purpose and change agentry with the associated capacities: personal vision; mastery; inquiry, and collaboration. Within the remainder of this paper, I draw on my observations and present excerpts of the interview data to evidence how the participant teachers acted as change agents: devising a personal vision for physical education, developing mastery through inquiry, and seeking out opportunities to increase their knowledge through collaboration with others.

\section{Background to the Teachers}

Acknowledging that context and structures work in parallel with individual agent factors, Lawson's (1983a\&b) model of teacher socialisation in physical education was used to analyse the teachers' physical education background stories and identify the contextual factors that shaped the teachers over time. Lawson defines three interrelated and overlapping phases of socialisation: acculturation, professional socialisation and organisational socialisation. Applying these phases to the teachers' background stories revealed a wide 
1 range of factors influencing their understanding and teaching of physical education, for

2 example, schools, colleagues, outside agencies and education policy (Carse, 2013). At the

3 acculturation phase the teachers were influenced by their past personal experiences of

4 physical education and physical activity. Max and Lara recalled very positive school

5 experiences of physical education, which they had wanted to recreate in their teaching. In

6 contrast, Imogen and Jackson had less positive school experiences, but had enjoyed engaging

7 in physical activity outside of school. Imogen and Jackson spoke of how their school

8 experiences made them want to improve the learning experiences for the children they were

9 working with.

Considering the professional socialisation of the teachers, they made scant reference to their experiences of physical education within their initial teacher education, but reflective of much of the literature (see Caldecott, Warburton, and Waring, 2006; Morgan and Hansen, 2008b) a consensus did emerge on the lack of time afforded to physical education. It was the organisational phase, mixed with acculturation experiences that appeared to be most influential on the teachers' approach to teaching physical education. In Scotland most primary schools have a visiting physical education specialist teacher; this emerged as being very significant to the teachers' professional learning. Each teacher discussed how, in the early stages of their careers, they had learned about teaching physical education mainly through working with the specialist teacher; this usually involved observing the specialist and then teaching a follow-up lesson. Concurrently, prior to undertaking the PgCert, the teachers described replicating a sport oriented curriculum in their teaching, as Max reflected: 'if I've loved playing sport..and been taught that skills and drills way and that made sense to me...and then if I see somebody else [the PE specialist] doing it perfectly well, why would I question 
1 it.' This quotation demonstrates how the teachers' experiences of physical education through

2 acculturation and organisational socialisation combined to influence their teaching practice.

\section{Teachers engaged in change agentry}

4

5

6

Analysing the teachers' physical education background experiences in relation to the professional development they had undertaken and their response to it suggested that the teachers had initiated change in their practice within their school contexts. The emergent themes arising from the data resonated with Fullan's (1993a\&b) work on change agentry, exemplifying the concept of informed professional judgment and the capacities for change: personal vision; mastery; inquiry, and collaboration.

\section{Informed professional judgement and personal vision}

The professional development (the PgCert) the teachers engaged with exposed them to 'external ideas as well as internal ideas, interaction and judgment' (Fullan, 2003: 7), which contributed to their development of 'informed professional judgment'. 'External ideas' around the education system and curriculum and pedagogical approaches emerged from the PgCert; this supported the teachers to revise their thinking around physical education and develop a collective understanding, what Fullan (1993a) describes as a 'shared vision'. This shared vision then became a resource for the teachers because as they 'interacted' with the contexts they were working in the shared vision combined with their 'internal ideas' into their personal vision. In contrast to their previous understanding of physical education, which had centred on activities and their teaching, the vision emerging from the PgCert centred on the children and learning (Carse, 2013). The following extracts from Lara and Jackson illustrate that the teachers' primary concern in their renewed personal vision was motivating, challenging and supporting the children they were working with: 
The subject areas [within physical education] I have chosen to go through with the children are based on as much as I can [their] choice and past experience. For the children there is still a real drive from them to have a traditional sense of physical education i.e. things like gymnastics and games and sport specific. So I have to bear that in mind and also try to match it with the developmental approach [advocated by the PgCert]. I'm trying to make it [physical education] motivational, inclusive and developmental; I'm trying to fit it into the community so it's relevant to them [the children]...Drawing on knowledge and experience from the children in the delivery too.

Similarly Jackson said:

It's not just about them [the children] sitting down and listening to me, it's about them contributing during the lessons and feeding off their energy and their ideas, it's not just me spoon-feeding answers. I'm now teasing out more from them, their actual experience...And it's not me, it's obviously part of the teaching, but they're getting it for themselves and they're learning it for themselves. So the key is obviously learning. You want there to be good learning, quality learning.

These extracts are indicative of the personal vision articulated by all of the teachers which were reflective in nature, focussed on the educational value of physical education and on children's learning experiences (Thorburn et al., 2011; Carse, 2013).

\section{Mastery and inquiry}

In line with Fullan's (1993a) description of mastery and inquiry as essential capacities for successful change the participant teachers were committed to extending and deepening their physical education knowledge and understanding. As the teachers experimented with new ideas in physical education lessons, enacted their personal vision and reflected on their 
1 practice they became immersed in a process of continuous learning that was embedded within

2 their everyday work, as Imogen reflected: You get all the information, you accommodate it and then you assimilate it and some of it I'm still assimilating, still working through. So I still pull out stuff from my folders and look through it...and actually the more you do it practically the more it becomes relevant...I think I'm actually a person who learns by doing not just by reading.

Much of the curriculum development the teachers initiated centred on modifying the multiactivity block programme they had previously delivered to make it more connected and developmentally appropriate; this involved experimenting with some of the different approaches the PgCert had introduced them to.

All of the teachers adapted the curriculum they were delivering in the early years (children aged 5 to 8) to use Basic Moves as a framework for exploring fundamental movement skills and the application contexts for these skills. I observed all the teachers deliver Basic Moves lessons which all followed a similar framework. After an introductory activity, which was often a game, the children would then explore movement through guided discovery supported by the teacher's questioning. The following extract from my fieldnotes of a Basic Moves lesson Imogen lead illustrates this:

Imogen asked the children to use the apparatus to go over, under and through. A discussion then takes place with the children on over, under and through which involves the children demonstrating. The children are then asked to go over, under and through with different body parts. Imogen asks the question: What body parts did you use? The children answer: feet, side, elbow, hands, tummy, back. 
1 Following on from the taught part of the lesson, the children had the opportunity to work

2 independently to apply the movement they had been learning at stations devised by the

3 teacher. These stations were carefully designed to encourage the children to be adaptable and

4 creative in their movement, whilst also affording the teacher the opportunity to focus their

5 attention at specific stations to work individually with the children. At the end of the lesson

6 the children were often given the opportunity to apply what they had been learning about

7 movement in an application/game context.

Although every teacher used this framework, Basic Moves was not viewed as a prescriptive programme to be followed, rather, as Max stated it was an 'ethos' which was 'open to interpretation'. The framework provided a structure for lessons and the curriculum, but the teachers decided the content of the lessons based on the context they were working in and the learning needs of the children they were working with. For all the teachers, as Imogen stated, it seemed to provide: 'scaffolding to support children to access games and physical activity.'

Complementary to Basic Moves all the teachers drew on a $\mathrm{TgFU}$ approach, attempting to teach through games and involve children in designing modified games. For example, Lara recalled how: 'I do make a lot of links across invasion games. I'll use sometimes the same sort of game or drill across the invasion games so the children can pick up on the links.' Building on her generic teaching of invasion games, Lara followed the interest of one of the upper primary classes (children aged 10 and 11) she was teaching to focus on hockey: 'I wanted the learning to be about the situated learning aspect of hockey. I wanted them to play the game and develop the skills through the game.' Accordingly, Lara provided the children with the opportunity to explore the tactics of hockey such as the use of space, by playing modified small-sided (four-a-side) games and full-sided (eleven-a-side) games which were 
1 video recorded and then self and peer assessed by the children to compare and contrast the 2 games:

They had a whiteboard, it was a tick frequency chart and they had their criteria [negotiated by the children], they had their four-a-side and then eleven-a-side and they had to tick every time they saw a good use of space, and whatever the other criteria were.

This example from Lara reflects a common theme that emerged for all the teachers in their approach to teaching games, that they took a more holistic approach. All of the teachers modified games in an attempt to better meet the children's learning needs and they provided opportunities for children to problem solve, exploring the tactics, principles and social aspect of game play as well as developing skills.

Lara, Max and Jackson also experimented with Sport Education in the physical education curriculum. Jackson spoke of being 'excited' about trying Sport Education, he felt that the time and energy he had put into it had 'really paid dividends', but at the same time recognised difficulties in this approach:

Running the four leagues and four classes that's probably why I found it tiring and just staying on top of the fixtures and keeping everybody right and working with the duty teams and points and just managing it all. It's enormous, absolutely enormous and I think I probably could have delegated [to the children] more.

Similarly, Lara also valued Sport Education as an approach and had used it extensively within her physical education curriculum. The response of the children Lara was working with towards Sport Education was also positive, affirming her use of this approach: 
I asked the children [in a written response] what they liked or disliked and learned from doing hockey through a Sport Education approach. You can see some of their responses: "It was fair." "We got to choose our practice sessions." "We learned to have fun" "We learned how to dribble." Some of them broke down skills: "we learned how to pass." So they felt they were getting more out of it: "it was more interesting", "it was evenly matched", "us choosing what to do", "I like doing the different roles".

Contrastingly Max was open in critiquing Sport Education: 'I'm not opposed to Sport $E d$ and all the roles... [but] do you want to sit on the side and be the referee, the scorer, the timer and stuff or do you just want to play the game.' Yet, despite his critique there were elements of Sport Education he liked and employed within his teaching. For example, I observed Max using elements of Sport Education to explore striking and fielding games, as the following extract from my fieldnotes exemplifies:

The children were asked to get into their teams and draw a t-shirt for their team; they had previously made a badge, mascot and hand shake for their team. I noticed a display on the wall that showed the mascots, badges and league table with points.

As the teachers enacted their personal vision and attempted to develop mastery they demonstrated a willingness to learn and viewed learning as a continuous and lifelong process; factors regarded as central to teachers developing the capacity to manage change (Hoban, 2002; Lasky, 2005).

\section{Connections and collaboration}

Implementing change the teachers worked independently and exercised their autonomy, however, as Fullan (1993a) highlights, there is a limit to how much can be learned 
1 individually. As the teachers developed confidence in their new physical education

2 knowledge, they sought opportunities to make connections across and beyond the curriculum and for collaboration. Making connections across the curriculum all the teachers discussed

4 how they had attempted to link with other curriculum areas, for example, Max mentioned

5 working with the class teachers in his school to incorporate literacy and numeracy, 'writing

6 letters to basketball clubs' and 'measuring jumps and throws in athletics'. The teachers also

7 spoke of employing their classroom practice into the physical education curriculum, for

8 example, Jackson spoke of using discussion and formative assessment strategies.

Making connections beyond the curriculum and with a view to seeking out opportunities for collaboration, the teachers attempted to connect with key stakeholders at a number of levels, community, local authority and school, as the following quotation from Lara exemplifies: collaboration.

Struggling to find opportunities for collaboration, it was evident that the teachers felt increasingly isolated within their school contexts. Imogen described being 'in a void of her own' within her school, while Lara described feeling frustrated within her school context: 
1 'having something and nobody knowing what it was I had'. Similarly, Jackson reflected on

2 his limited opportunity to collaborate with colleagues in his school:

Yeah I think anybody will listen to me but generally my feeling is and I think probably their feeling is too, although it's maybe unspoken, is that they've got their stuff to be getting on with, I've got my remit to be getting on with, they don't want my remit and I don't want their remit so we just kind of work in that respect.

Seeking out opportunities for collaboration the teachers all expressed wanting a network where they could share their experiences, get advice and meet people in similar situations to themselves.

In particular, a desire was articulated to observe other physical education specialist teachers and PgCert graduates teaching, as Max passionately stated:

I would love to [observe people in other schools] but it's never going to happen. We had a day [in-service] at X Secondary School and people were talking and they were talking about sort of sharing and monitoring and stuff and I said: "this is a totally ridiculous conversation because it is never going to happen, there's no point in even talking about it." In a primary school [doing] a PE teacher's job, it's not [possible] so we shouldn't talk about it.

Within his school context Max grew increasingly frustrated with the limited opportunities to collaborate with other teachers. Max wanted to carry out peer observations, but the structure of the school day, the limited knowledge and interest of colleagues and the solitary nature of teaching physical education negated against his efforts. Despite the value of collaborative approaches to learning, networks and peer observation being advocated within Scottish education policy (Scottish Government, 2011), the experiences of the participant teachers in 
1 this study would suggest that engaging in these collaborative activities, within the 'real'

2 context of the school is 'easier said than done'.

\section{Discussion}

The research reported on in this paper explored how teachers construed and took

5 forward curriculum change following engagement with accredited, long term professional

6 development. The work of Fullan was specifically used to analyse how the individual

7 teachers worked at curriculum change within their school contexts. Through this theoretical

8 lens it is possible to see how the teachers responded to the professional development they had

9 undertaken to develop informed professional judgement, which underpinned their change agentry work as they enacted their personal vision and sought to improve their practice and modify the curriculum.

Reflecting on the findings of the study factors can be identified which enabled and constrained the teachers' change efforts. One of the main enabling factors contributing to the teachers' agency to facilitate change was their engagement with long-term professional development, the PgCert. This professional development was a significant event in the professional lives of the participant teachers; it impacted on their professional socialisation (Lawson, 1983a\&b) and motivated them to instigate curriculum change (Carse, 2013). In relation to the teachers' professional socialisation, the PgCert critiqued the traditional multiactivity block, sport orientated approach to physical education, which had previously dominated their own learning in physical education and their practice as teachers.

Contrastingly, the PgCert encouraged the teachers to critically analyse their practice in physical education and introduced them to holistic, social constructivist and more childcentred pedagogical approaches which promoted learning in and through physical education (Thorburn et al., 2011). Furthermore, rather than prescribing a specific programme to follow, 
the professional development provided by the PgCert challenged the teachers, encouraging them to exercise their agency and utilise their professional autonomy to develop a physical education curriculum grounded within their individual school contexts (Carse, 2013).

The teachers were also aided in their change efforts by the juxtaposition of the supportive policy environment, yet still marginal status of physical education within the primary curriculum. Away from the glare of narrow accountability measures, but with policy in place which affirmed their change efforts, the teachers could exercise their agency to plan and deliver a physical education curriculum that met the needs of their learners and took account of their local context. As Lara stated, no one was 'breathing over the shoulder' of the participant teachers scrutinising what they were doing which provided time and space to initiate change. Priestley (2007) asserts that: 'many successful reforms have succeeded because they engendered professional trust and a genuine shift in power to those at the chalk face' (p. 44). Similarly, the findings from this study suggest that one of the main facilitating factors of the teachers' change efforts was the professional autonomy they were able to exert within their school contexts which contributed to their ownership of the change process.

Despite there being a number of factors supporting the change efforts of the participant teachers, there were also constraining factors. The main factor constraining the change efforts of the teachers was a feeling of isolation, stemming from the issues encountered as they attempted to collaborate with colleagues and other physical education practitioners. At times the teachers were also restrained by the 'grammar of schooling' in the form of: timetabling; conventional academic subjects, such as maths and language taking precedence within the curriculum; a focus on accountability measures, and the 'flat' management structure (Hargreaves and Goodson, 2006; Tyack and Cuban, 1995).

Furthermore, the teachers had to overcome the generally 'traditional' sport and games 
1 perceptions of physical education held by the children and their colleagues. Whilst

2 challenging, these negative factors illuminate the messy nature of the change process at the

3 'chalk face' and the many contextual factors that contribute to the sustainability of change

4 (Fullan, 1993a).

\section{Conclusion}

6 At the beginning of this paper it was intimated that centrally driven reforms have failed

7 to take account of the central role of teachers in the change process, leaving the profession

8 feeling frustrated and marginalised. Contrastingly, the study reported on in this paper

9 provides fine-grained empirical evidence of teachers initiating change, within their school

10 contexts. Following engagement in professional development, the teachers became involved

11 in a process of curriculum change, as they reviewed their practice and modified the

curriculum. Interviewing and observing the teachers provided an insight into the links

between professional development and curriculum change whilst also illuminating the process of teaching and learning in physical education. Furthermore, analysis of interview and observation data provided an in-depth understanding of the teachers' thinking and behaviour within their school settings.

While the fine-grained data generated by this small scale research provides a detailed picture of teachers' and their work, I acknowledge that there are a number of limitations in the research. Firstly, because the experiences of individual teachers were investigated indepth, it was not possible within the scope of the study to explore corresponding factors influencing change at the macro level in the same depth. Secondly, focussing on the teachers' meant that it was not possible to fully investigate the impact of their change efforts on children's learning; this is an area which requires further research and would contribute to a gap in the literature on the effectiveness of professional development in relation to the 
1 learning of children.. Finally, given the small scale nature of the study, I don't seek to

2 generalise, but hope that the in-depth data generated sheds light on the complex nature of

3 curriculum change and the central role of the teacher in this process.

4

5

6

For those charged with developing policy and practice the findings from this paper indicate how, when engendered with professional trust (Priestley, 2007) teachers can exercise their agency to take a lead role in shaping the curriculum (Lasky, 2005). The data generated by this study also suggests various factors that may contribute to teacher agency enabling teachers to view change as a process they are part of rather than a reform foisted upon them, these include:

- long term professional development;

- time and space for teachers to become immersed in the change process; reflecting on and then improving their practice through continuous learning, and

- genuine opportunities for collaboration and professional dialogue where teachers can develop networks, undertake peer observations and engage in collaborative professional learning.

These factors are reflective of the literature on educational change which highlights the need for teachers to have ownership and an understanding of change as a process (Fullan, 1993a\&b; Hoban, 2002; Priestley, 2011). This study intimates that if teachers are to take on the mantle of change agents, opportunities for teachers to examine the complex process of change and their role within this process should be recognised by policy makers and incorporated into professional development and initial teacher education. 
2 Bailey, R., Armour, K., Kirk, D., Jess, M., Pickup, I., and Sandford, R. (2009) The

3 educational benefits claimed for physical education and school sport: an academic review.

$4 \quad$ Research Papers in Education 24(1): 1-27.

5 Boeije, H. (2010) Analysis in Qualitative Research. London: Sage Publications Ltd.

6 Bogdan, R. and Biklen, S. (1982). Qualitative Research for Education: An Introduction to 7 Theory and Methods. Boston: Allyn and Bacon Inc.

8 Bryman, A. (2008) Social Research Methods, New York: Oxford University Press

9 Bunker, D. and Thorpe, R. (1982) A model for the teaching of games in the secondary 10 school. Bulletin of Physical Education 10: 9-16.

11 Carse (2013) 'Change is a Journey': investigating the complex process of educational change within Scottish primary physical education. PhD Thesis, University of Edinburgh UK.

14 Caldecott, S., Warburton, P. and Waring, M.(2006) A survey of the time devoted to the 15 preparation of primary and junior school trainee teachers to teach physical education in 16 England, British Journal of Teaching Physical Education, 37(1): 44-48.

17 Charmaz, K. (2006) Constructing Grounded Theory: a practical guide through qualitative 18 analysis. London: Sage.

19 Chen, C. (2005) Teachers as Change Agents: A Study of In-Service Teachers' Practical 20 Knowledge. Action in Teacher Education 26(4): 10-20. 
1 Cohen, L., Manion, L. and Morrison, K. (2007) Research Methods in Education Sixth

2 Edition. Oxon: Routledge.

3 DeCorby, K., \& Halas, J. (2005). Classroom teachers and the challenges of delivering quality

4 physical education. The Journal of Educational Research, 98(4), 208-220.

5 Denscombe, M. (2007) The Good Research Guide: for small-scale social research projects

$6 \quad$ third edition. Maidenhead: Open University Press.

7 Denzin, N. and Lincoln, Y. (1998) Strategies of Qualitative Inquiry. London: Sage

8 Publications.

9 Ertmer, P. A. and Ottenbreit-Leftwich, A. T. (2010) Teacher Technology Change: How

10 Knowledge, Confidence, Beliefs, and Culture Intersect. Journal of Research on Technology

11 in Education 42(3): 255-284.

12 Evans, J. (2013) Physical Education as porn! Physical Education and Sport Pedagogy 18(1):

$13 \quad 75-89$.

14 Fraser, C., Kennedy, A., Reid, L. and Mckinney, S. (2007) Teachers' continuing professional

15 development: contested concepts, understandings and models. Journal of In-Service

16 Education, 33(2): 153-169.

17 Freeman, D. (1982) Observing Teachers: Three Approaches to In-Service Training and

18 Development. TESOL Quarterly 16(1): 21-28.

19 Fullan, M. (1993a) Change Forces. London: The Falmer Press.

20 Fullan, M. (1993b) Why Teachers Must Become Change Agents. Educational Leadership

21 50(6): 1-13. 
1 Fullan, M. (1999) Change Forces the Sequel. London: The Falmer Press.

2 Fullan, M. (2003) Change Forces with a vengeance. London: The Falmer Press.

3 Gray, S., Mulholland, R. and MacLean, J. (2012) The ebb and flow of curriculum

4 construction in physical education: a Scottish narrative. The Curriculum Journal 23(1): 59-

578.

6 Griggs, G., and Ward, G. (2012) Physical Education in the UK: disconnections and

7 reconnections. The Curriculum Journal 23(2): 207-229.

8 Hardman, K. and Marshall, J. (2001) The state and status of physical education in schools in 9 international context. European Physical Education Review 6(3): 203-229.

10 Hargreaves, A. and Goodson, I. (2006) Educational Change Over Time? The Sustainability 11 and Nonsustainability of Three Decades of Secondary School Change and Continuity.

12 Educational Administration Quarterly 42(1): 3-41.

13 Harris, A. (2011) Reforming systems: Realizing the Fourth Way. Journal of Educational 14 Change, 12(2): 159-171.

HMIE (2001) Improving Physical Education in Primary Schools. Edinburgh: HMIE.

Hoban, G. (2002) Teacher Learning for Educational change: a systems thinking approach.

17 Buckingham: Open University Press. Jess, M. and Campbell, T. (2012) The Scottish Primary Physical Education Project (Part 2): From Traditional CPD to Long Term Professional Learning. Physical Education Matters 8 (2): $48-51$. 
1 Jess, M., Dewar, K. and Fraser, G. (2004) Basic Moves: Developing a Foundation for

2 Lifelong Physical Activity. British Journal of Teaching in Physical Education 35(2): 23-27.

3 Kirk, D. (2004) Physical education, youth sport and lifelong participation. European Physical $4 \quad$ Education Review 10: 95-108.

$5 \quad$ Kirk, D. (2010) Physical Education Futures. London: Routledge.

6 Kirk, D. and Macdonald, D. (2001) Teacher voice and ownership of curriculum change.

7 Journal of Curriculum Studies 33(5): 551-567.

8 Kirk, D. and Macphail, A. (2002) Teaching Games for Understanding and Situated Learning :

9 Rethinking the Bunker-Thorpe Model. Journal of Teaching in Physical Education 21: 177-

10192.

11 Lasky, S. (2005) A sociocultural approach to understanding teacher identity, agency and 12 professional vulnerability in a context of secondary school reform. Teaching and Teacher 13 Education 21(8): 899-916.

14 Lawson, H. (1983a) Toward a model of teacher socialization in physical education: The 15 subjective warrant, recruitment, and teacher education. Journal of Teaching in Physical 16 Education 2(3): 3-16.

17 Lawson, H. (1983b) Toward a model of teacher socialization in physical education: Entry 18 into schools, teachers' role orientations, and longevity in teaching. Journal of Teaching in 19 Physical Education, 3(1), 3-15.

20 Morgan, P. and Hansen, V. (2007). Recommendations to improve primary school physical 21 education: classroom teachers' perspective. The Journal of Educational Research, (August 22 2011), 37-41. 
1 Morgan, P. J. and Hansen, V. (2008a). Classroom Teachers' Perceptions of the Impact of

2 Barriers to Teaching Physical Education on the Quality of Physical Education Programs.

$3 \quad$ Research Quarterly for Exercise and Sport, 79(4), 506-516.

4 Morgan, P. J., \& Hansen, V. (2008b). Physical education in primary schools: Classroom

5 teachers' perceptions of benefits and outcomes. Health Education Journal, 67(3), 196-207.

6 Morse, J., Barrett, M., Mayan, M., Olson, K. and Spiers, J. (2002) Verification Strategies for

7 Establishing Reliability and Validity in Qualitative Research. International Journal of

$8 \quad$ Qualitative Methods 1(2): 1-19.

9 Newby, P. (2010) Research Methods for Education. Harlow: Pearson Education Ltd.

10 Penney, D. (2013) Points of tension and possibility: boundaries in and of physical education.

11 Sport, Education and Society 18(1): 6-20.

12 Penney, D. and Chandler, T. (2000) Physical Education: What Future(s)? Sport, Education and Society 5(1): 71-87.

Penney, D. and Jess, M. (2004) Physical education and physically active lives: a lifelong approach to curriculum development. Sport, Education and Society 9(2): 269-287.

Priestley, M. (2007) The Social Practices of Curriculum Making, EdD Thesis, University of

17 Stirling, UK.

Priestley, M. (2010) Curriculum for Excellence: transformational change or business as usual? Scottish Educational Review 42(1): 23-36.

20 Priestley, M. (2011) Schools, teachers, and curriculum change: A balancing act? Journal of Educational Change 12(1): 1-23. 
1 Priestley, M., Edwards, R., Priestley, A., and Miller, K. (2012) Teacher Agency in

2 Curriculum Making: Agents of Change and Spaces for Manoeuvre. Curriculum Inquiry $3 \quad 42(2): 191-214$.

4 Punch, K. (2009) Introduction to Research Methods in Education. London: Sage Publications 5 Ltd.

6 Scottish Executive (2003) Lets make Scotland more active: A strategy for physical activity.

7 Edinburgh: HMSO.

8 Scottish Executive (2004) The report of the review group on physical education. Edinburgh:

9 HMSO.

10 Scottish Government (2008) Curriculum for Excellence Building the Curriculum 3: a

11 framework for teaching and learning. Edinburgh: Scottish Government.

12 Scottish Government (2011) Report of a review of teacher education in Scotland: teaching

13 Scotland's future. Edinburgh: Scottish Government.

14 Siedentop, D. (1994) Sport Education: quality PE through positive sport experiences,

15 Champaign, Ill.: Human Kinetics.

16 Silverman, D. (2010) Doing Qualitative Research: a practical handbook third edition.

17 London: Sage.

18 Thorburn, M., Jess, M., and Atencio, M. (2011) Thinking differently about curriculum:

19 analysing the potential contribution of physical education as part of 'health and wellbeing'

20 during a time of revised curriculum ambitions in Scotland. Physical Education and Sport

21 Pedagogy 16(4): 383-398. 
1 Thorburn, M., Carse, N., Jess, M and Atencio, M. (2011) Translating change into improved

2 practice: Analysis of teachers' attempts to generate a new emerging pedagogy in Scotland.

3 European Physical Education Review 17(3): 313-324.

4 Tinning, R. and Glasby, T. (2002) Pedagogical Work and the 'Cult of the Body': Considering

5 the Role of HPE in the Context of the 'New Public Health'. Sport, Education and Society

$6 \quad 7(2): 109-119$.

7 Tyack, D. and Cuban, L. (1995) Tinkering Toward Utopia: A Century of Public School

8 Reform. Cambridge, Mass.: Harvard University Press.

9 Wright, J. (2004). Critical inquiry and problem-solving in physical education. In: J. Wright,

10 D. Macdonald, and L. Burrows (eds.), Critical Inquiry and Problem-Solving in Physical

11 Education. London: Routledge, pp. 3-15.

12

13

14

15 